Article

\title{
Non-Antagonistic Contradictoriness of the Progress of Advanced Digitized Production with SARS-CoV-2 Virus Transmission in the Area of Dental Engineering
}

\author{
Leszek A. Dobrzański ${ }^{1, *(1)}$, Lech B. Dobrzański ${ }^{1}{ }^{\mathbb{C}}$, Anna D. Dobrzańska-Danikiewicz ${ }^{2}$, \\ Joanna Dobrzańska ${ }^{1}$, Karolina Rudziarczyk ${ }^{1}$ and Anna Achtelik-Franczak ${ }^{1}$ \\ 1 Medical and Dental Engineering Centre for Research, Design and Production ASKLEPIOS, 13 D Krolowej \\ Bony St., 44-100 Gliwice, Poland; dobrzanski@centrumasklepios.pl (L.B.D.); \\ joanna.dobrzanska@centrumasklepios.pl (J.D.); Karolina.rudziarczyk@centrumasklepios.pl (K.R.); \\ anna.achtelik-franczak@centrumasklepios.pl (A.A.-F.) \\ 2 Department of Mechanical Engineering, University of Zielona Góra, 4 Prof. Z. Szafrana St., \\ 65-516 Zielona Góra, Poland; anna.dobrzanska.danikiewicz@gmail.com \\ * Correspondence: leszek.dobrzanski@centrumasklepios.pl; Tel.: +48-606-33-55-66
}

Received: 13 August 2020; Accepted: 2 September 2020; Published: 4 September 2020

\begin{abstract}
The general goals of advanced digitized production in the Industry 4.0 stage of the industrial revolution were presented along with the extended holistic model of Industry 4.0, introduced by the authors, indicating the importance of material design and the selection of appropriate manufacturing technology. The effect of the global lockdown caused by the SARS-CoV-2 virus transmission pandemic was a drastic decrease in production, resulting in a significant decrease in the gross domestic product GDP in all countries, and gigantic problems in health care, including dentistry. Dentists belong to the highest risk group because the doctor works in the patient's respiratory tract. This paper presents a breakthrough authors solution, implemented by the active SPEC strategy, and aims to eliminate clinical aerosol at the source by negative pressure aspirating bioaerosol at the patient's mouth line. The comparative benchmarking analysis and its results show that only the proprietary solution with a set of devices eliminates the threat at the source, while the remaining known methods do not meet the expectations. The details of this solution are described. Photopolymer materials and additive Digital Light Printing (DLP) technology were used.
\end{abstract}

Keywords: industry 4.0; dentistry 4.0; SARS-CoV-2 pandemic; SPEC strategy; elimination clinical aerosol at the source; dendrological matrix; photopolymer materials; additive digital light printing

1. General Goals of Advanced Digitized Production in the Industry 4.0 Stage of the Industrial Revolution

Since the end of the 18th century, the industrial revolution has progressed. Nowadays, the world has reached the Industry 4.0 stage related to the dissemination of cyber-physical systems CPS [1-5]. They provide communication between machines and smart products and create a virtual copy of the physical world via digital twins that can be subjected to virtual experiments, much cheaper and faster than the experimental verification of products in industrial practice. Apart from the cyber-IT module, the real progress is determined by the development of advanced engineering materials, multifaceted and various technological processes, including additive ones as part of them, and machines, and technological devices [6-8]. The augmented holistic model of Industry 4.0, introduced by the authors in the form of an octahedron, includes in its technological platform all four components that require systematic development (Figure 1) [7,8]. 


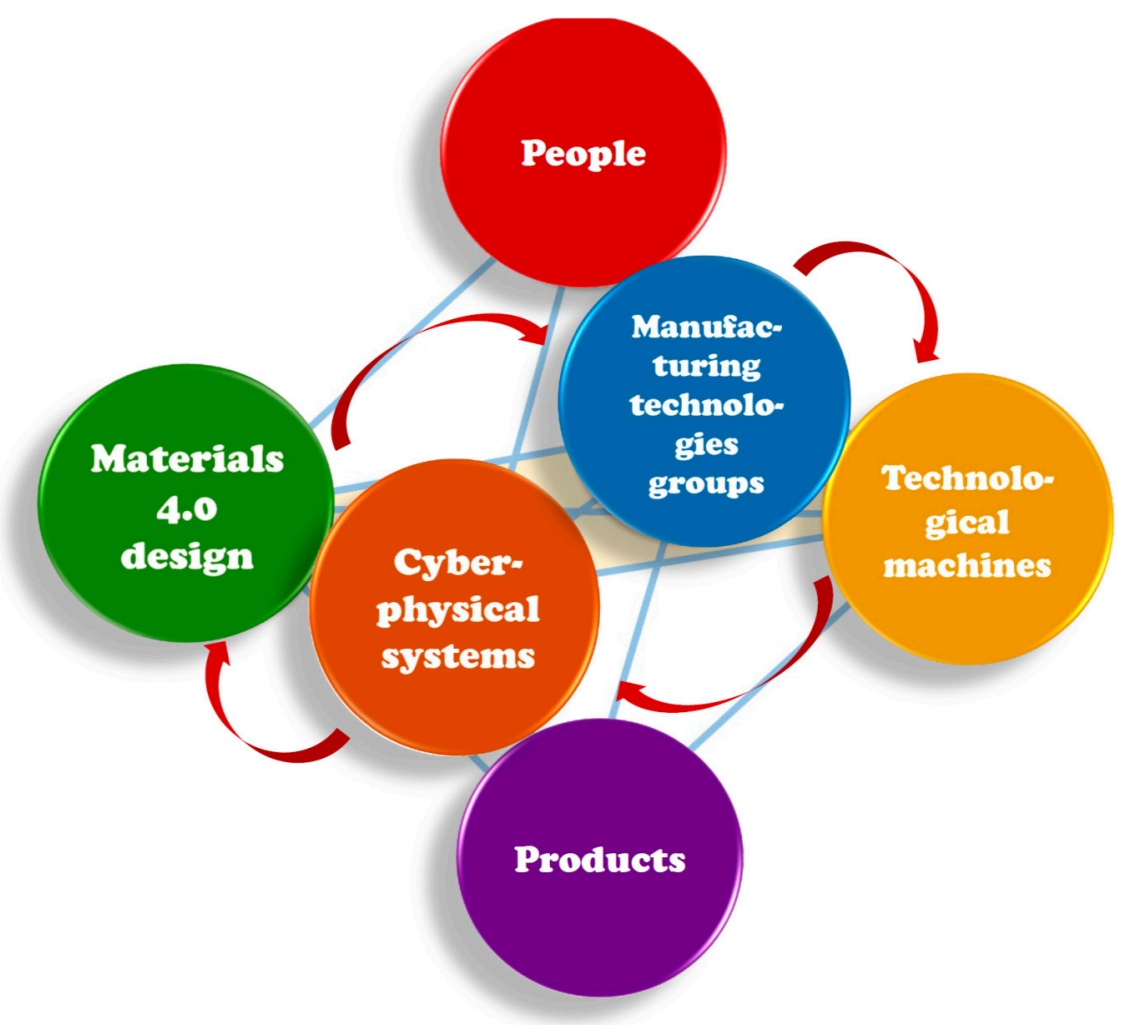

Figure 1. Diagram of the augmented holistic Industry 4.0 model in the form of an octahedron.

New technologies result in Integrated Sustainable Industrial Development (ISID) by bringing new goods to the market and improving production efficiency. By combining hardware, software, and connectivity, advanced digital production technologies (ADP) are spreading (Figure 2) [9].

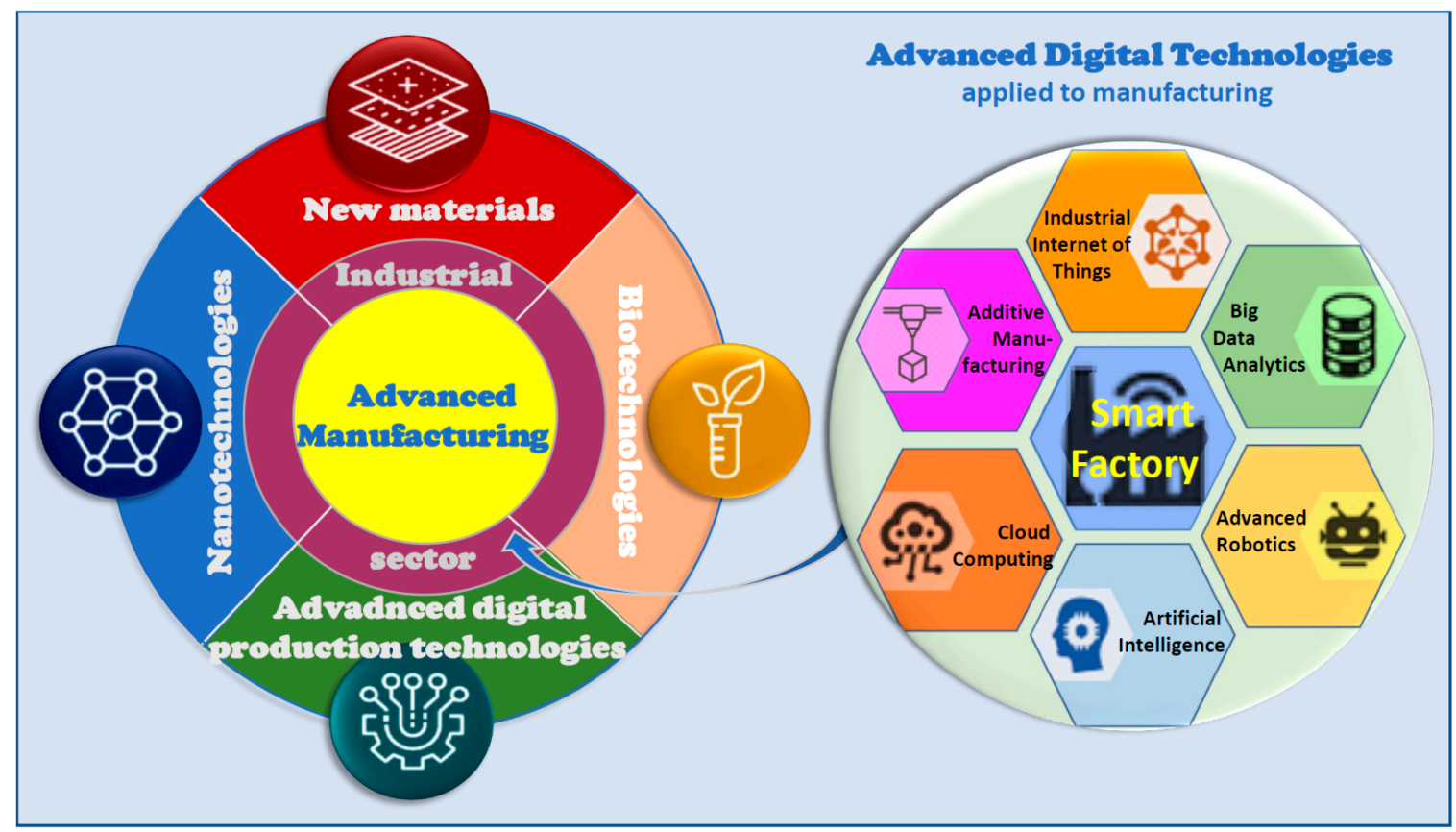

Figure 2. Diagram of advanced digital production and advanced technologies applied to manufacturing 
For obvious reasons, it is in the general interest that these advanced digital production technologies be shared by the widest possible group of subjects in the world. It is increasingly difficult to imagine the design and manufacture of any product without intensive computer-aided manufacturing and manufacturing requiring significant IT support. Until recently, it seemed that the cause and effect chain of progress was clearly defined and that it could not be disrupted in any way. Unfortunately, the experimental life verification in the last few months has not confirmed this seemingly obvious view.

\section{Multifaceted Implications of the COVID-19 Disease Pandemic Caused by SARS-CoV-2 Virus Transmission}

On 20 March 2020, the World Health Organization declared a pandemic of the severe and acute respiratory syndrome and other severe diseases of the human body defined as the COVID-19 coronavirus 2019 disease. It is caused by the transmission of the severe acute respiratory syndrome coronavirus SARS-CoV-2 virus, which is a small nano-sized natural object with a diameter of 60-140 nm and a spherical shape, although somewhat pleomorphic, surrounded by bright spines 9-12 nm long, making it similar to a corona (Figure 3) [10].

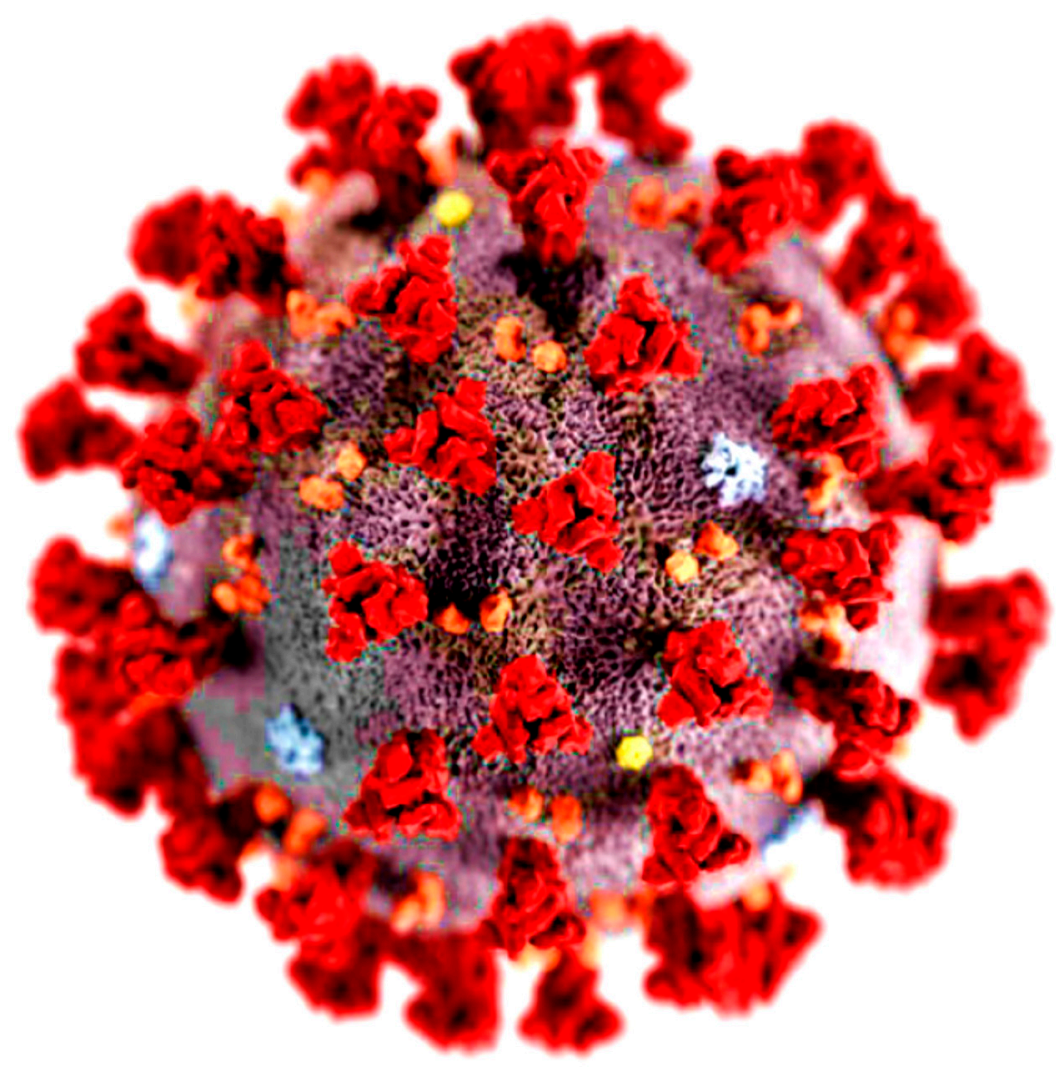

Figure 3. Visualization of SARS-CoV-2 virus.

The genome of this enveloped virus is positive polarity single-stranded ribonucleic acid. The size of this virus is 100 trillion times smaller than the size of the globe. With its arrival, virtually everything in the world has changed. The scale of the pandemic spanned the entire world, and in nearly 20 weeks of its announcement globally, as of 3:36 pm Central European Summer Time (CEST), 3 August 2020, there have been 17,918,582 confirmed cases of COVID-19, including 686,703 deaths, reported to World Health Organization WHO [11] (Figure 4). 


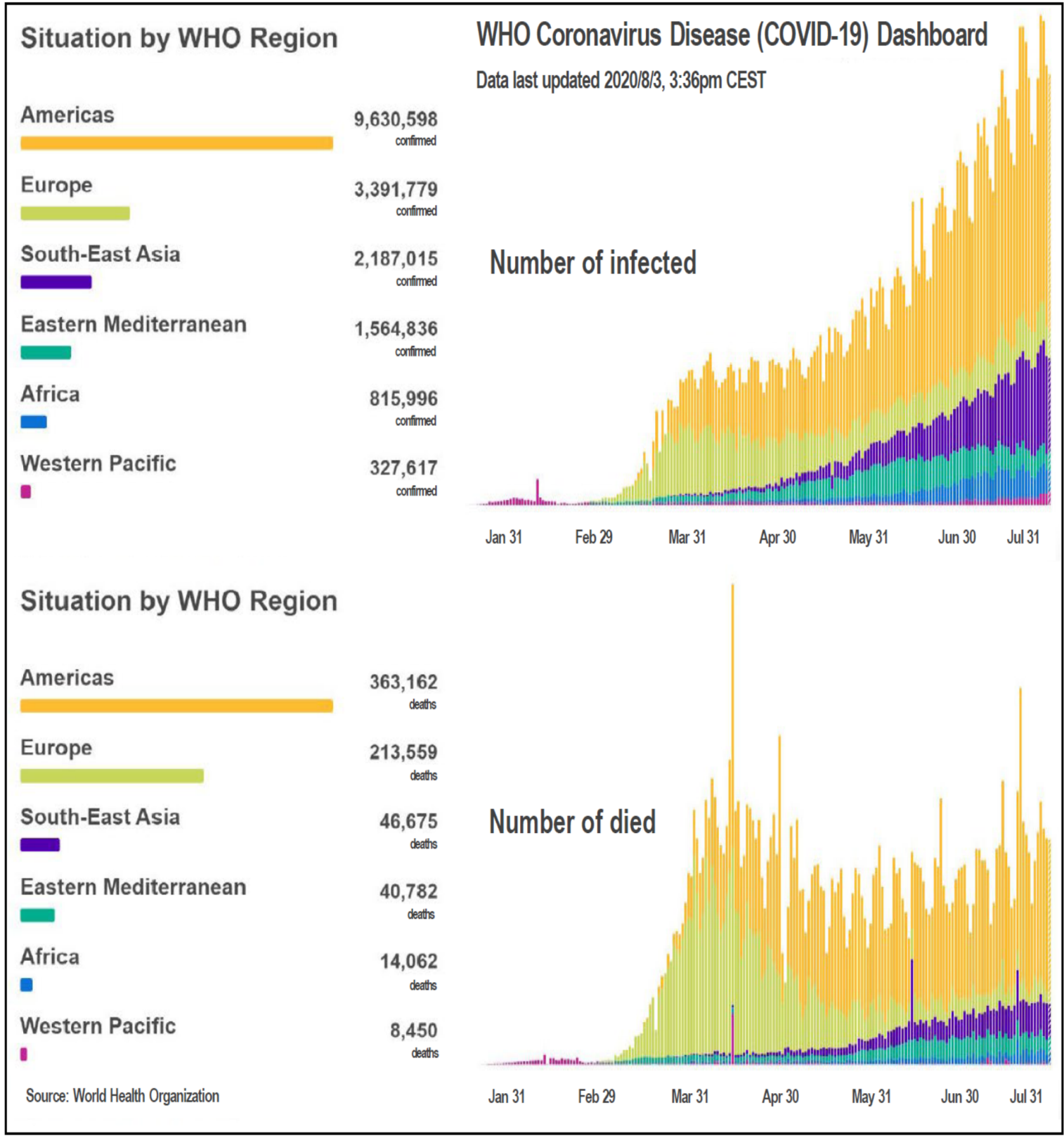

Figure 4. Graphs of changes in the number of infected and dead during the COVID-19 pandemic.

Statistically, these are huge numbers, comparable to the victims of road accidents, in which, according to WHO data, over 1.2 million people lose their lives annually in the world. The data of the European Agency for Safety and Health at Work (EU-OSHA) show that, for example, in 2017, 3362 people died in Europe, and 380,500 in the world, which is much less than the number of victims of coronavirus in the period of approx. four months.

Since the start of the COVID-19 pandemic, various national governments have taken numerous restrictive measures. The effect of the global lockdown was a drastic decrease in production, and the closure, and even many times liquidation of many industrial enterprises, as well as limiting or extinguishing activity in many other industries, resulting in a significant decrease in the gross domestic product (GDP) in Q2 2020 in all countries (Figure 5) [12] and enormous organizational problems in health care units and hospitals all over the world. 
Of course, it applies mainly to infectious hospitals but causes significant perturbations in many other branches of medicine, ranging from limiting the number and scope of medical services to the complete abandonment of their provision. It even leads to deaths for reasons not directly related to COVID-19 disease, but indirectly due to it, due to gross negligence in other areas of treatment. It is the case in dentistry, where, due to the high probability of SARS-CoV-2 virus transmission in dental clinics, the US, European and Brazilian governments recommended that these clinics be closed for the first many weeks. Several dental associations around the world require dentists to postpone scheduled procedures. For example, in Poland, on 15 July 2020, by the decision of the Ministry of Health, the prohibition of normal dental practice in full force was renewed from the beginning of the pandemic, in favor of working in the emergency mode. It would be irresponsible to continue to practice in a dentist's clinic even with personal protective equipment PPE under these conditions. One of the reasons is the uncertainty about the incubation time of the virus, which is estimated at 5 to 6 days, with a range of up to 14 days [13], and even its reappearance in cured patients. More than 3000 medical workers in 79 countries around the world have died due to the disease caused by SARS-CoV-2 coronavirus [14]. According to WHO data, dentists are among the doctors at the highest risk. As a result of natural respiration processes, during dental procedures performed in the patient's open mouth, the bioaerosol exhaled by him, in the area of the nasal and oral cavity, in addition to air, also includes viruses, bacteria, and fungi, including pathogenic, abundantly absorbed by the patient while breathing. Due to the necessity of bringing the physician's face close to the patient's mouth within a clear vision distance (up to $20 \mathrm{~cm}$ ), considering that even $5-10 \mathrm{~cm}$ of this distance is in the patient's mouth, the doctor inhales most of the patient's exhaled air along with pathogenic microorganisms.

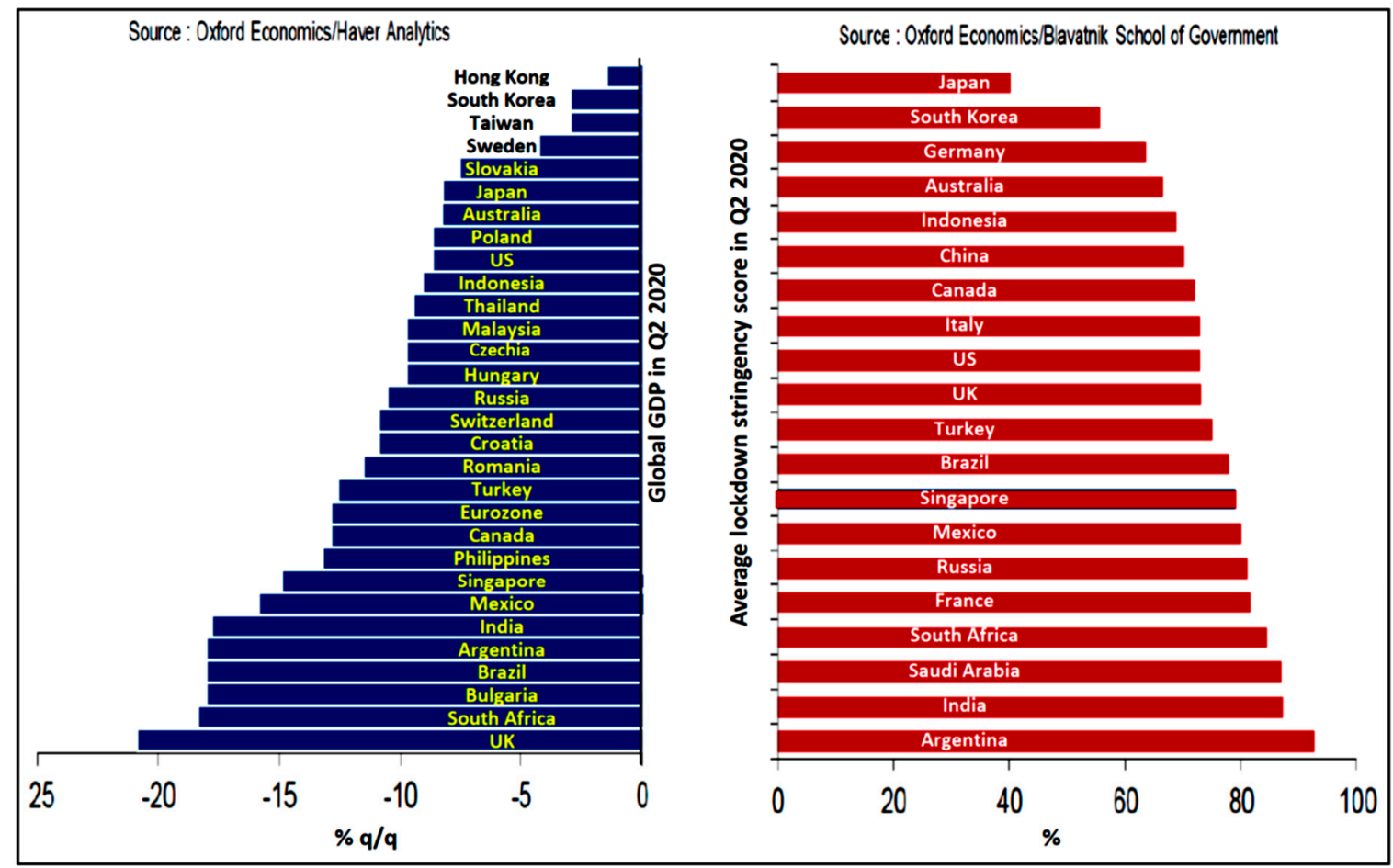

Figure 5. Fall in the gross domestic product (GDP) in the second quarter of 2020 in various countries and the lockdown stringency score.

In the case of any infection of the patient's respiratory tract, the doctor is exposed to the direct transmission of various microorganisms multiplied in the upper and lower respiratory tract of the patient, including the SARS-CoV-2 coronavirus, contained in the patient's exhaled air, as well as colloidal particles of secretion sprayed by him when coughing or sneezing, which are colloidal particles of bioaerosol. In particular, the possibility of SARS-CoV-2 coronavirus transmission in the form of 
bioaerosols exists even with normal breathing [15]. The problem is all the greater as the use of a turbine, or even a high-speed motor, to prepare the teeth requires intensive cooling, and the cooling jet mixed with the infected saliva and blood of the patient is intensely atomized, and the clinical aerosol is mixed with the respiratory bioaerosol, disproportionately increasing the dentist and dental staff risk. Usually, all treatments require an assistant and the so-called work for four hands. Considerable pollution of the environment by SARS-CoV-2 patients by droplets from the respiratory tract and excretion of saliva mixed with blood suggest the environment as a potential medium of transmission and the necessity to strictly observe the hygiene of the environment and hands [16]. This poses a great risk of directly infecting dentists and medical assistants in particular. In addition, some asymptomatic or subclinically infected patients with mild symptoms are also contagious, leading to the possibility of the virus spreading unintentionally in dental clinics. The mechanism is presented in Figure 6, and the transmission of infection during a week of asymptomatic infection by a dentist may reach a thousand or more people. In the last 20 weeks, every dentist practicing despite the pandemic has come across such cases.

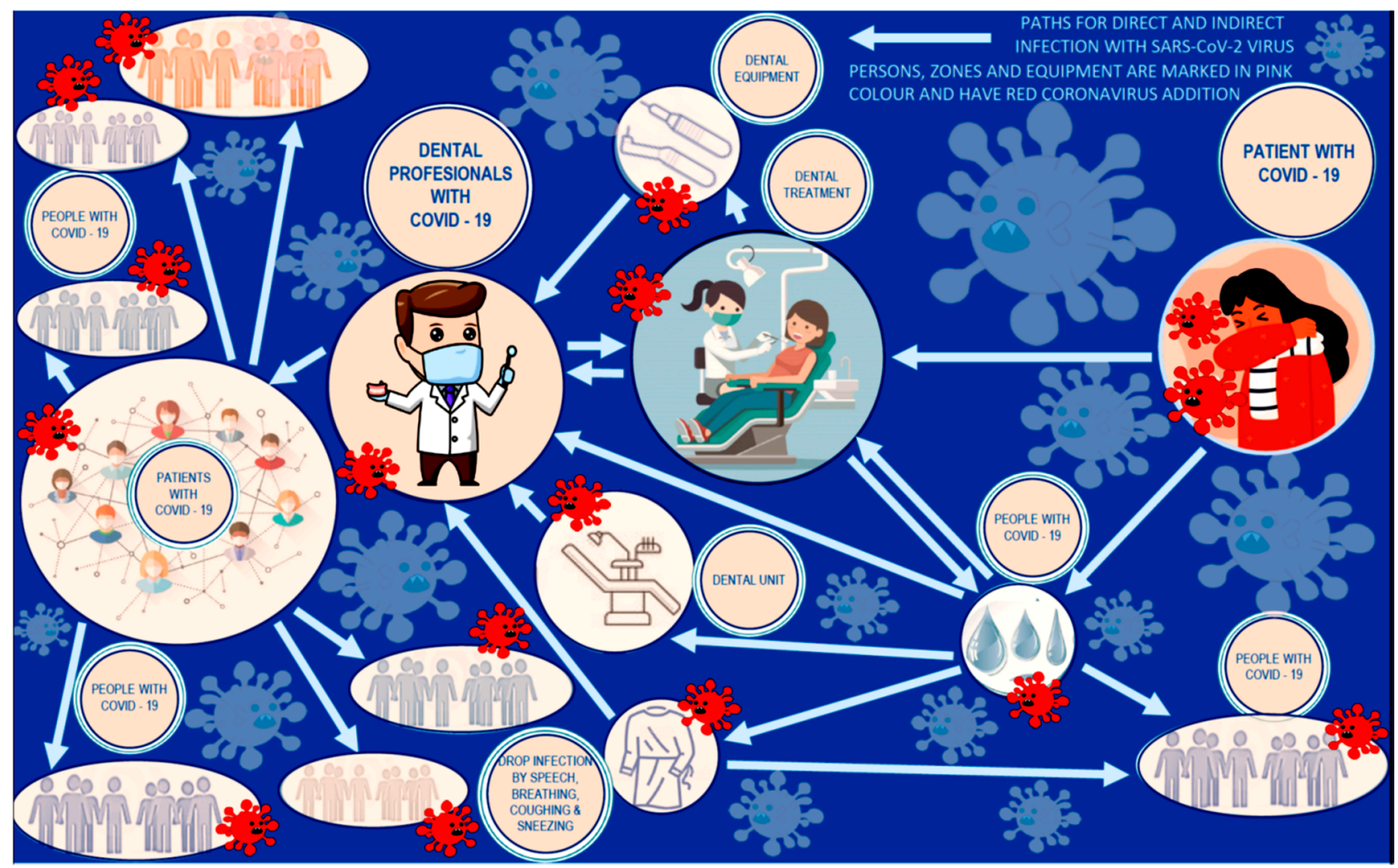

Figure 6. The mechanism of transmission of coronavirus infection by a dentist during a week of asymptomatic infection.

In view of the global efforts to promote social distancing, practical strategies to block the transmission of SARS-CoV-2 virus during dental diagnosis and treatment include a complete patient health assessment, stringent hand hygiene, personal protective equipment for dentists, rinsing the patient's mouth prior to dental procedures, isolation by a cofferdam, surgery disinfection, a surgical mask and eye protection with solid side shields or a face shield protecting the mucous membranes of the eyes, nose, and mouth during procedures, proper management of medical waste [17]. Thus, the STOP strategy is common, and in fact keeps up to date with the intensification of personal protective equipment (PPE), which is a solution contested by dentists. In fact, the society of doctors and the dental staff was deprived of the chance to return to normal working conditions, and the medical administration responsible for it did not present any reasonable proposals, except the suggestion addressed to doctors to avoid most procedures outside the emergency ones mainly with patients' pain [18-22]. In essence, it is an expectation that dentists not fulfill their obligations resulting from 
the Hippocratic oath, most commonly known and used nowadays after numerous modifications as the World Medical Association WMA Declaration of Geneva [23], which is made by every doctor who takes up employment in his profession. Even a basic rule was not respected-first, don't harm. The doctor, despite the fact that he risks his life and health, in accordance with the regulations and recommendations in force in many, perhaps even all countries, is obliged to refrain from providing most of the dental services [18-22]. It applies without exception to all or almost all dental offices, with full awareness of nonchalance in exposing the health of doctors and dental staff to a lethal threat at each subsequent visit of a patient, who may be asymptomatic or may have COVID-19 within 14 days of incubation and unconscious emission of infection.

In the opinion of the authors of this paper, it is an unacceptable situation from every possible point of view: ethical, legal, protection of employee interests, protection of the patient's interest, violation of constitutional rights to health protection, violation of the European Union's priorities in terms of improving the comfort and extension of human life, protection, or rather systematic violation of human rights in general [24]. In this situation, it is obvious that solutions should be sought, among other technical, which will prevent such unfavorable state of affairs.

\section{The Concept of Elimination of the Mixture of Bioaerosol with Pathogenic Microorganisms and Clinical Aerosol in the Conditions of Performing Dental Procedures}

This paper presents a ground-breaking authors solution that allows to solve this problem systematically and enable dentists to perform their daily work and provide all services related to the performance of a full range of dental procedures without restrictions, but with all necessary precautions. The solution is protected by a patent [18]. Works related to the serial production of the device on the market were commenced [19]. The analysis of the novelty of this solution indicates a complete change in the approach to solving the problem and a change in the way of thinking about it, making it fully unrivaled and ground-breaking in terms of its approach and essence.

A completely new SPEC strategy was applied, which was developed by the authors of this paper (Figure 7). It replaces the commonly used STOP approach in the world to solve problems of protecting medical staff in the event of an epidemiological threat. In the STOP strategy successively, more and more radical approaches are implemented, ranging from system solutions, through technical solutions, organizational solutions to the implementation of personal protection equipment. As a result, doctors and nurses are completely isolated from the environment in which are present the patients who are infected and emit pathogenic pathogens to this environment or only are suspected of being infected. By the way, the medical staff, in this case, cannot move freely, they sweat, and they are not able to perform many precise activities necessary for the needs of medical procedures. It is a passive way of preventing the effects of a pandemic or epidemic.

SPEC strategy combines a simultaneous and synergistic approach to actively solving the problem of protection against pathogenic pathogens. It combines a systemic approach, prevention, efficiency, and, most importantly, ensures the elimination of the cause and, in addition, at the source of the threat. As a result, doctors and nurses can effectively perform their medical tasks in an environment that is not contaminated by an infected patient. Their movements are not restrained, and there are no barriers to a good vision by them of the area in which medical procedures are performed.

One should hit the cause, not deal with the effect, and the causative factor should be eliminated, not tolerated, or at best weakened. While the STOP strategy is defensive and conservative, and therefore it could not lead to any solution to the problem, especially the new one, the original SPEC strategy is the essence of activity and action and that is why it led to an innovative solution of the problem.

This solution is a collection of many comprehensive devices. Its task is to eliminate the clinical aerosol at its source from the space of the dental office by collecting it directly into an epidemiologically safe container and its complete deactivation and decontamination, and not indirect isolation of medical personnel from pathogenic aerosol and tolerating its presence in the entire space of the dental clinic. 
Figure 8 shows the modular structure of the dental staff protection system against the SARS-CoV-2 coronavirus and other pathogenic microorganisms. An important part of the accessory is the face cap (1), and its successive variants provide an ever wider range of accessory functions, causing negative pressure around the patient's mouth and nose and allowing the patient to aspirate bioaerosol.

The accessory also contains an extractor (2) which aspirates the patient's saliva and blood to the residues settlers (5) and (6), in which the aerosol exhaled by the patient condenses, and in both sedimentation tanks bacteria, viruses and other pathogenic microorganisms and their spores are destroyed by chemical disinfection under appropriate conditions and taking into account the elimination of risks for personnel resulting from the toxicity of the applied. Then the aerosol, pre-cleaned of microorganisms, is subjected to radiation (7), e.g., using ultraviolet radiation, filtering (8) e.g., with activated carbon, and is sucked by a suction pump (9) providing a negative pressure throughout the system to direct the purified air to the next filtration (10), and then after leaving the system directly through the pipe (11) to the atmosphere outside from laboratory rooms or to a central ventilation system. In this variant, the accessory is equipped with a nasal cannula (14) suitably attached (15) to the face cap (1) connected to an external breathing aid unit (16) in order to balance the pressure in the patient's airway against the negative pressure in the oro-space the patient's nasal passages. The system of (12) devices (5)-(10) and oxygen cylinders are mounted in an integrated housing with lockable wheels (13), allowing free movement of the entire accessory running gear in the room.

One of the elements of this device is a completely originally designed face cap, which protects the entire space of the dental office and all people present in it. It is not a filter, and this is a major novelty. However, due to the size of the coronavirus from $40 \div 150 \mathrm{~nm}$, any available mask worn by medical personnel does not provide any protection, because the minimum size of the pores in the filters of the most effective masks is at least $2 \div 7.5$ times larger, therefore no mask meets its requirements role. Figure 9 shows a range of face caps, each with more and more integrated functions.
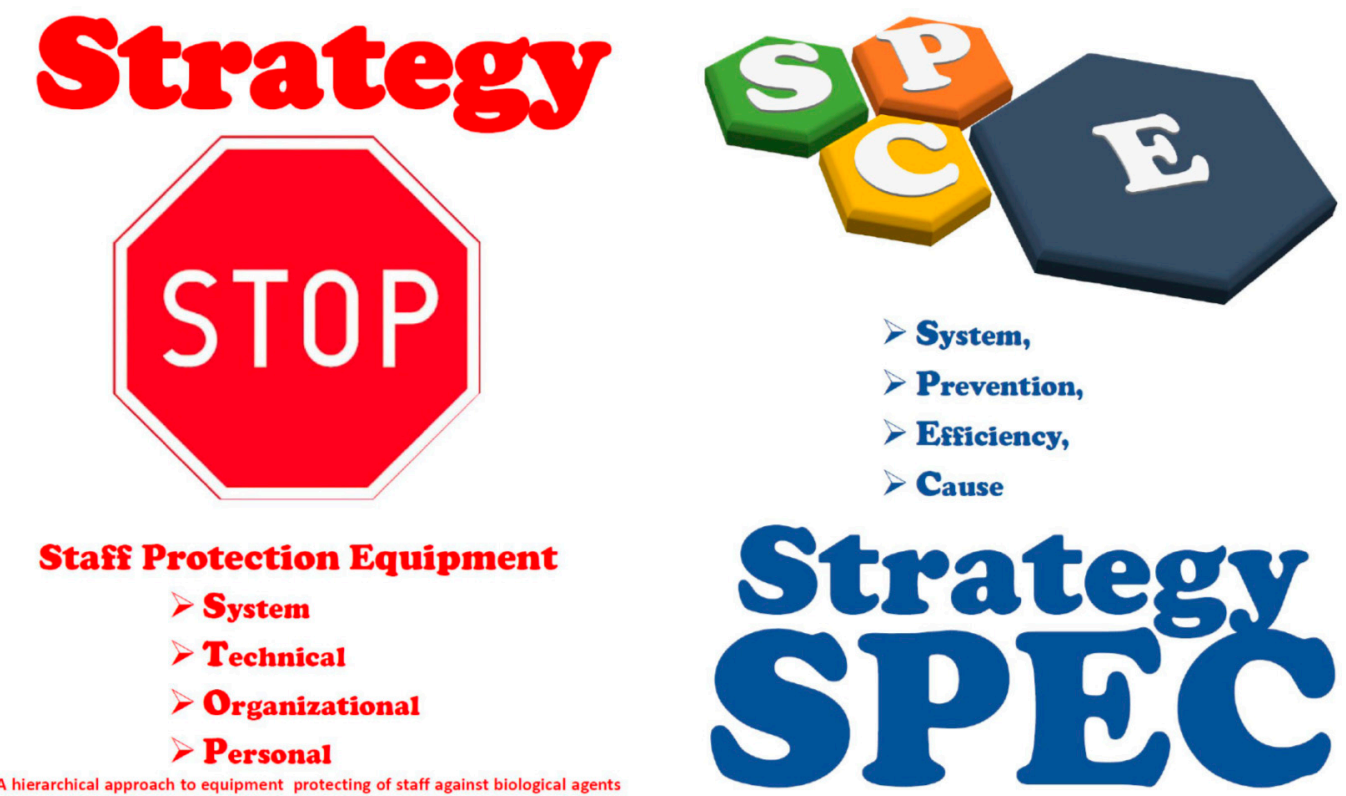

Figure 7. Comparison of the basic assumptions of the conservative STOP strategy and the offensive SPEC strategy. 


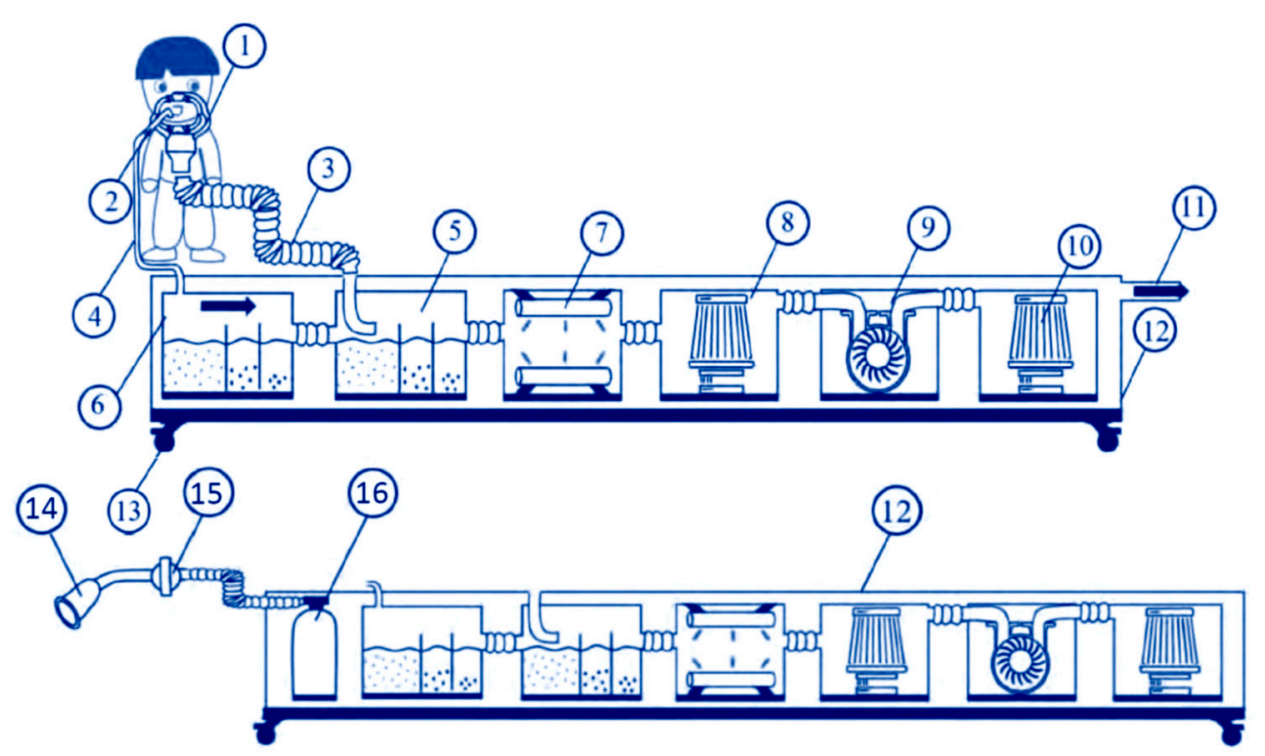

Figure 8. The modular structure of the dental personnel protection system against the SARS-CoV-2 coronavirus and other pathogenic microorganisms.

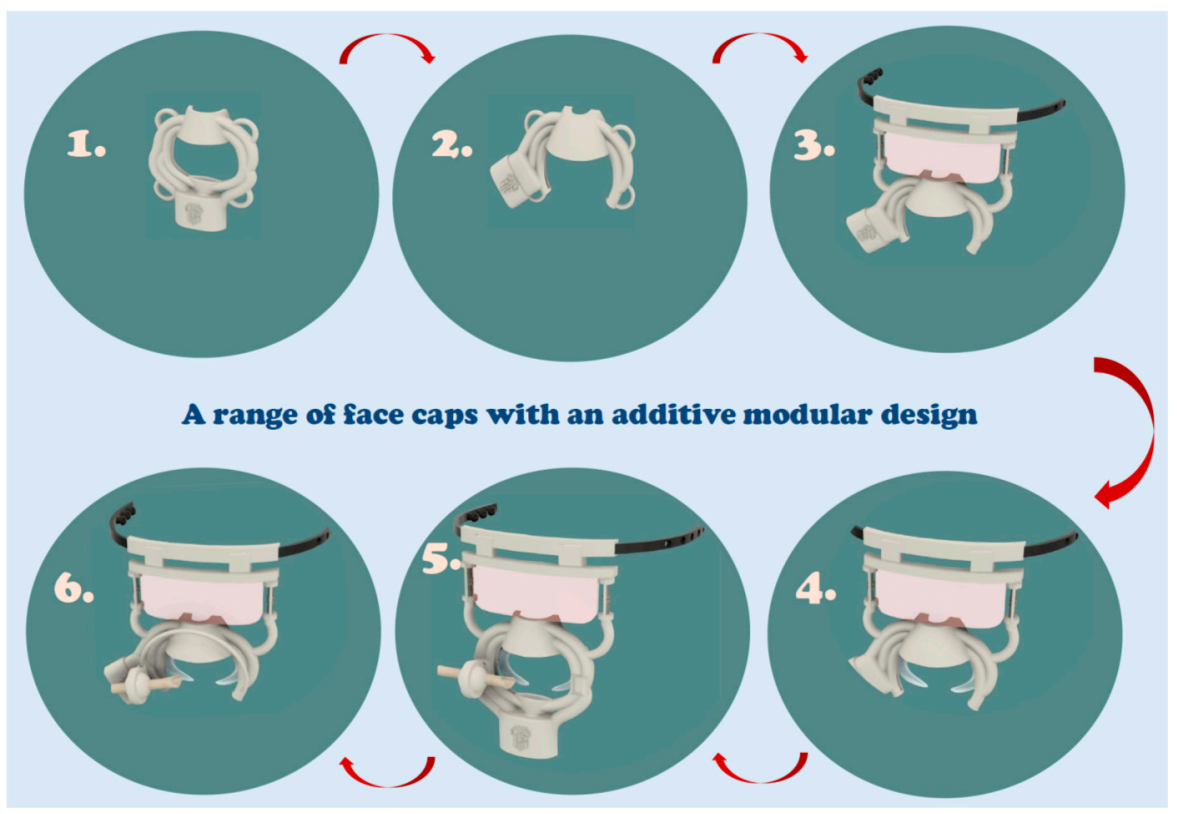

Figure 9. A range of face caps, each of which performs more and more integrated functions.

Figure 10 shows one of the most advanced versions of the face cap, and the symbology of road signs explains how it works. In its basic version, the face cap has an oval through shape and, as in any other functional variant, has an integrated structure and is composed of four tubes of approximately equal length, which requires insertion in the shortest spiral section. The sections of tubing surrounding the oval through-shape have a partially open " $\mathrm{C}$ "-shaped section with the obtuse portion facing the interior of the oval shape, in order to suck the bioaerosol around the patient's mouth during operation. The tubes are incorporated into a centrally located manifold, preferably in a rectangular cross-section with rounded tops, most often smoothly circular in section, allowing for dismountable connection to the flexible tubing. The face cap is placed with the flat side over the patient's face in such a way as to ensure full access to the patient's mouth by the doctors and the assistants. In order to stabilize the position of the face cap in relation to the patient's face, a flexible rubber band is mounted in the ears with the possibility of adjusting the length and pressure force, placed around the patient's head. 
When connected to a system with a suction pump, a negative pressure is generated around the inner circumference of the oval through-shape, with a value regulated by the pump power, as a result of which the bioaerosol exhaled by the patient, mixed with the clinical aerosol, is sucked, creating a zone free from pathogenic or highly limited microorganisms ambient air concentration above the outer face of the face-shield. In more advanced versions, the face cup includes a shaped nose cup with the lower oval shape exposed. The collector can be centrally located, and in the versions with an exposed lower part of the oval shape, it has a collector located on the left or on the right, which significantly improves the ergonomic features of the solution, giving the doctor various chances of choice. The shaped nose piece allows the aerosol to escape from the naso-facial zone. In order to stabilize their position in relation to the patient's face, these variants of face caps have two sets of lugs for mounting elastic rubber bands with adjustable length and pressure, placed around the patient's head. Another integrated set of face caps has two bows via two distance adjustment turnbuckles connected to a slightly curved mounting bar, to which are attached two shaped spring-loaded latches aligned at respective recesses through an eccentric with a shaped bar. The cross-section of this strip has the shape of a slotted rectangle through which an elastic band is threaded with a set of holes at one end of the band and a set of hooks with heads enabling the band to be fastened around the patient's head and to adjust its length to the circumference of the head. The strip is integrated with a transparent, limited-width eye curtain, which protects, apart from the patient's eyes, also medical personnel against accidental infection. The hinges with spring-loaded latches allow two positions of the face-cap, i.e., the working position when pressed against the face and the position after a vertical rotation of $180^{\circ}$, where the face-piece is raised and inside out towards the environment. During the procedures, the face cap is always placed in the working position and is connected to the system of hoisting and winding devices. In addition, the integrated set, analogous to the previous one, is additionally equipped with two-wing tilting and appropriately profiled mouthpieces enabling the opening of the patient's lips during treatments performed in the oral cavity. Mouthpieces by means of snaps with ball heads are pressed into the appropriate openings of the face cap with the internal shape of a ball-less a segment of the ball. The mouthpieces are attached as needed by pressing into the integrated outer layer of the face cap. The integrated kit can furthermore have two lugs for fixing the ball joint in a seat in the shape of a central press-fit layer mounted in the lugs integral with the outer layer of the face shield by a latch. In the axis of the ball joint situated in the socket in the shape of the central layer of the sphere, a tube is inserted in a way that allows axial movement due to the elastic features of the tube with a suitably profiled flattened tip of the saliva's extractor. The described system of connections allows the superposition of the longitudinal movements of the tube and its rotation in two planes so that the tip of the mammal can, in any situation, be located in the patient's oral cavity required for the needs of the dental procedure. The integrated set (Figure 10), in addition to the double-winged mouthpieces and the tip of the suction device, is additionally equipped with a headband mounted on the outer surface opposite to the face of the face cap over which the clamp is moved by the end of the suction cap and the nasal cannula connected to the external breathing support unit of the patient to balance the positive pressure in the patient's airways in relation to the negative pressure in the oronasal space of the patient, which is part of the system of suction devices. 


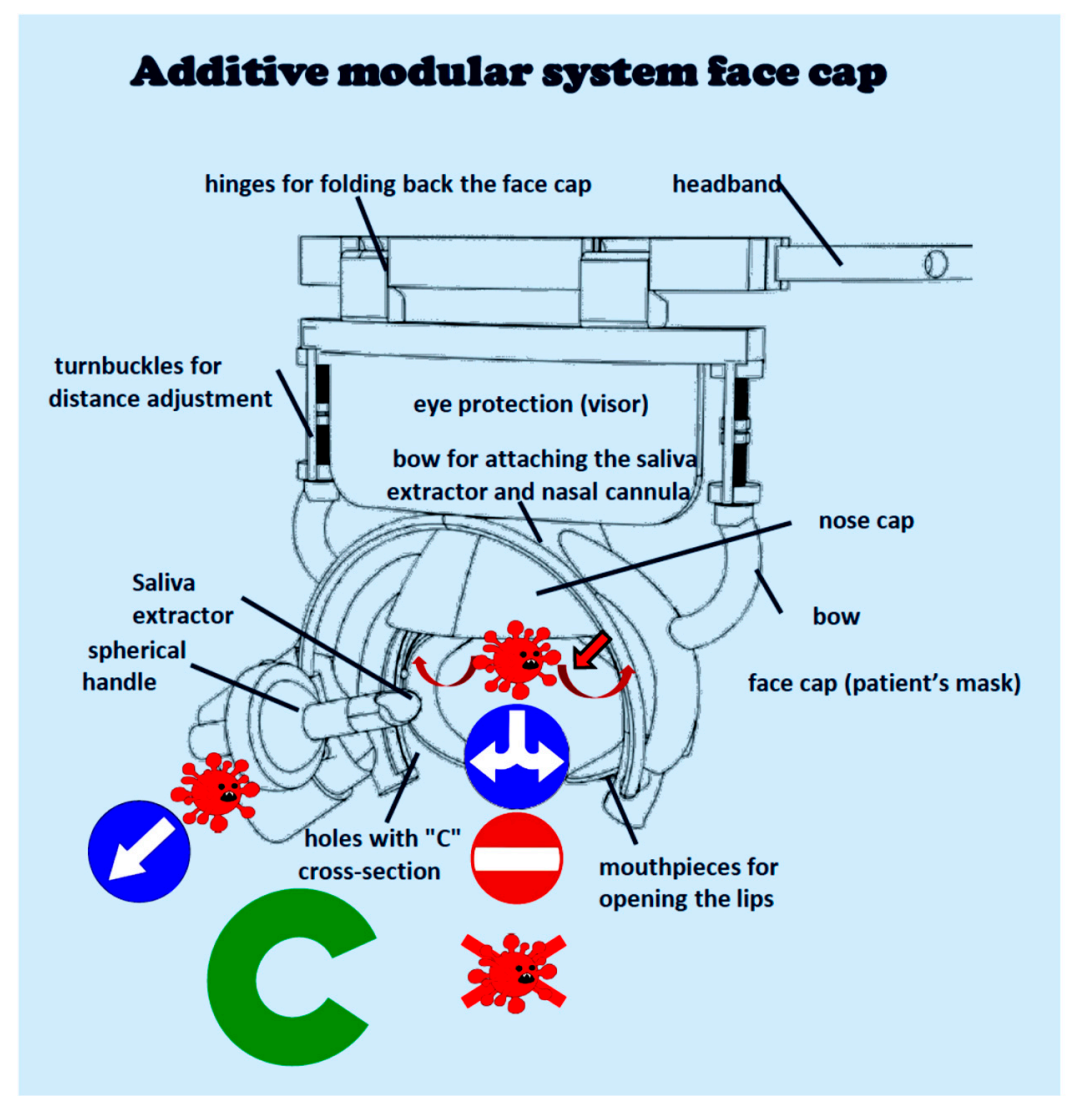

Figure 10. Diagram of the operation of the advanced face cap.

4. Comparative Assessment of the Authors Solution against the Available Methods of Protection against the Effects of the SARS-CoV-2 Coronavirus

In order to compare the methods of protection against the effects of the SARS-CoV-2 coronavirus, the authors used the scientific comparative method of procedural benchmarking in the field of knowledge engineering, developed by the authors and repeatedly tested (although in other subject areas), described in [20]. Each of these groups of methods has different attributes, so it is difficult to consider them similar, although by definition all of them are intended to improve epidemiological safety and, therefore, they are included in the considerations.

The procedural benchmarking method is based on a comparative analysis of these methods in terms of their potential and attractiveness. The point of view of medical personnel was adopted, which is faced with the choice of a method of effective protection against pathogenic virus infection, assuming that all procedures related to the widely understood clinical practice in the field of dentistry can be performed. As part of the expert assessment of the potential of the methods used, five basic criteria and five subsequent criteria were taken into account in assessing the attractiveness of the method, as given in Table 1. The methods were assessed in terms of the above-mentioned criteria of potential and attractiveness using the universal scale of relative states. It is a unipolar positive scale with no zero, with 1 being the weakest and 10 being the best. Moreover, each of the analyzed criteria, which are listed below, was given a weight which determines the importance of a given criterion for the overall evaluation of a given method. The higher the weight, the more the criterion influences the final weighted average. All groups of methods currently encountered, classified in the lower part of Table 1 in six groups, were taken into account, and the results of expert evaluation expressed numerically (from 1 to 10), calculated with the use of the authors computer program, were given in the appropriate columns. 
Table 1. Criteria for comparative evaluation of groups of methods of protection against the effects of SARS-CoV-2 coronavirus.

\begin{tabular}{|c|c|c|c|c|c|}
\hline No & Criterion & Weight & No & Criterion & Weight \\
\hline \multicolumn{3}{|c|}{ Potential } & \multicolumn{3}{|c|}{ Atttractiveness } \\
\hline P1 & Effectiveness of eliminating the risk of coronavirus & 0.50 & A1 & The sense of security of medical personnel & 0.50 \\
\hline P3 & Comprehensive approach & 0.10 & A3 & Difficulties in applying the method & 0.20 \\
\hline $\mathrm{P} 4$ & Safety of cleaning elements & 0.10 & $\mathrm{~A} 4$ & Importance for the profitability of the practice & 0.05 \\
\hline P5 & Installation cost & 0.05 & A5 & Impact on the clinics' development prospects & 0.05 \\
\hline
\end{tabular}

The results of the calculations are presented in Table 2 and graphically with the use of a dendrological matrix, presented in Figure 11. This matrix consists of four fields related to trees, intuitively indicating the potential and attractiveness as well as development prospects of the analyzed groups of methods. The methods with high potential and attractiveness include only the authors solution (6), which is located in the "Wide-stretching oak" quarter and is characterized by the greatest amount of novelty, presented in an objective manner. The field "Rooted dwarf mountain pine" includes proven, mature methods $(1,2)$, which have high potential, but may be of complementary importance, in cooperation with the one discussed first (6). "Soaring Cypress" is a quarter containing highly attractive methods $(3,4)$, with opportunities for the future, but requiring consolidation, otherwise they will not be successful in their application. The weakest quadrant is "Quaking Aspen". In this field, there are methods with little potential and attractiveness (5), i.e., methods that will be replaced by other, better solutions. The results of the assessments were plotted on a dendrological matrix. Among all the analyzed groups of methods, in terms of novelty compared to other methods, as well as potential and attractiveness, the authors solution (6) eliminating the threat at the source with a set of virus elimination devices clearly stands out.

Table 2. The results of calculating the potential and attractiveness of groups of methods of protection against the effects of SARS-CoV-2 coronavirus.

\begin{tabular}{cccc}
\hline No & $\begin{array}{c}\text { Type of Method Known in the Literature, } \\
\text { State-Of-The-Art Including Own Solution }\end{array}$ & Potential & Attracti Veness \\
\hline 1 & $\begin{array}{c}\text { Installation of air filtering devices in the treatment room } \\
\text { Equipment operating with HEPA or carbon filters or with }\end{array}$ & 6.7 & 4.0 \\
UV radiation & 5.95 & 4.0 \\
3 & $\quad$ Dental saliva extractor attachments & 3.3 & 5.8 \\
4 & "Extract from the treatment area" devices & 3.7 & 6.6 \\
5 & $\begin{array}{c}\text { Patient enclosures in the form of glass or PMMA boxes } \\
6\end{array}$ & 1.45 & 3.9 \\
& $\begin{array}{l}\text { Original solution eliminating the threat at the source with } \\
\text { the set of devices for virus elimination }\end{array}$ & 9.0 & 8.5 \\
\hline
\end{tabular}

The comparative analysis and its results indicate that only the authors solution (6) with a set of devices for virus elimination eliminates the threat at the source, while the other groups of methods available on the market and known from literature and company reports are relatively much more attractive (subjective impression of the recipient) than their potential (objective technical analysis). It means that it is commonly felt their role is overestimated despite their less factual meaning. None of the current solutions exceeded both potential and attractiveness (fairly low to moderate) in any of the ratings, which proves the poor usefulness and real ineffectiveness of these methods in removing sources of infection. The author's solution receives these scores as very high, respectively 9 (potential) and 8.5 (attractiveness-there are difficulties at work). This proves the unrivaled importance of this solution and its groundbreaking importance. 


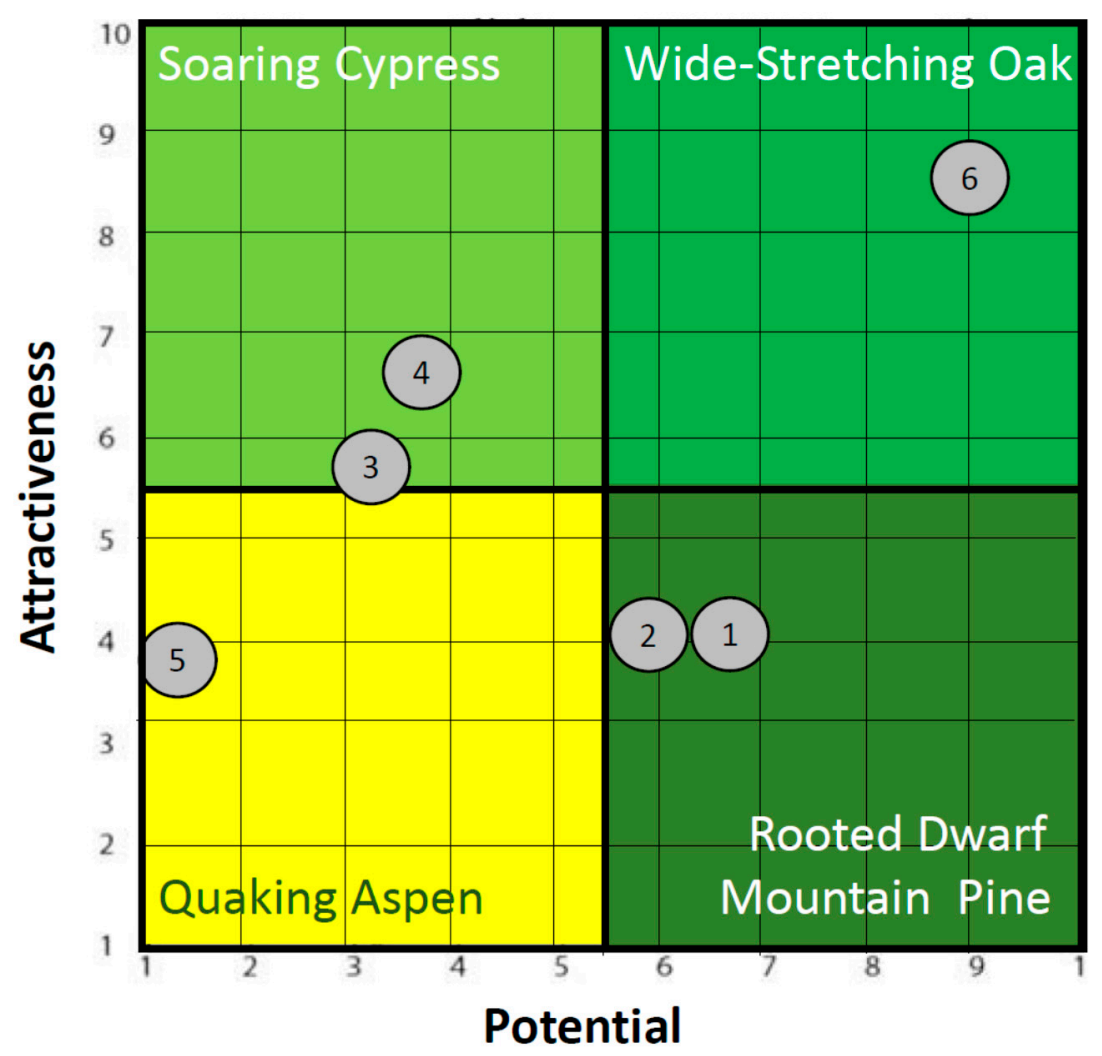

Figure 11. Dendrological matrix of methods of protection against the effects of SARS-CoV-2 coronavirus.

The essential element determining this high comparative rating is, of course, the virus capture efficiency (Figure 12). Our own solution (6) is effective due to the location of the virtual plane of the pressure difference as close as possible to the patient's mouth, and the elimination of bioaerosol takes place practically at the source of its production, preventing its diffusion beyond the patient's face. As a result, the expiratory the patient's bioaerosol mixed with the clinical aerosol is captured, and the so-called fit factor, which is the ratio of the captured aerosol to its total volume, is at least $99 \%$. The sequence of devices and the negative pressure in it protect the entire clinic space against the diffusion of any pathogenic microorganisms. Each coronavirus captured as a result is eliminated at the next stages of the device's operation, which gives $100 \%$ efficiency in the elimination of coronaviruses that go to the elimination system. The result is a real radical reduction in the concentration of viruses and harmful microorganisms in the space of the dental clinic. The solution applies to four-handed work for all types of dental procedures. All competing solutions in the best variant most often partially reduce the concentration of coronaviruses in the area of the mouth and nose of the patient but cause them to blow out at the end of the system in the same or adjacent room, which in turn does not protect the medical team from potential infection. One of such examples representing the group marked as (3) presented recently on the Internet is not an effective solution due to the relatively large, several centimeters distance of the mouth of the saliva ejector suction nozzle adapted to suck the aerosol from the area of the patient's face (Figure 12), which, however, allows for the spreading of bioaerosol by diffusion in the entire volume of the treatment room, sucking only a part of it, and because it does not contain decontamination system of bioaerosol. 


\section{Own eflective solution}

It is an effective solution due to the location of the virtual plane of the pressure difference at the closest possible distance from the patient's mouth, and the elimination of bioaerosol occurs practically at the source of its generation, preventing its diffusion beyond the patient's face.

\section{Another inelective solution}

Another solution, presented on the Internet, is an ineffective due to the relatively large, several centimeters distance of the saliva ejector suction tube outlet from the

patient's face, which allows bioaerosol to spread through diffusion in the entire environment and without a bioaerosol decontamination system.
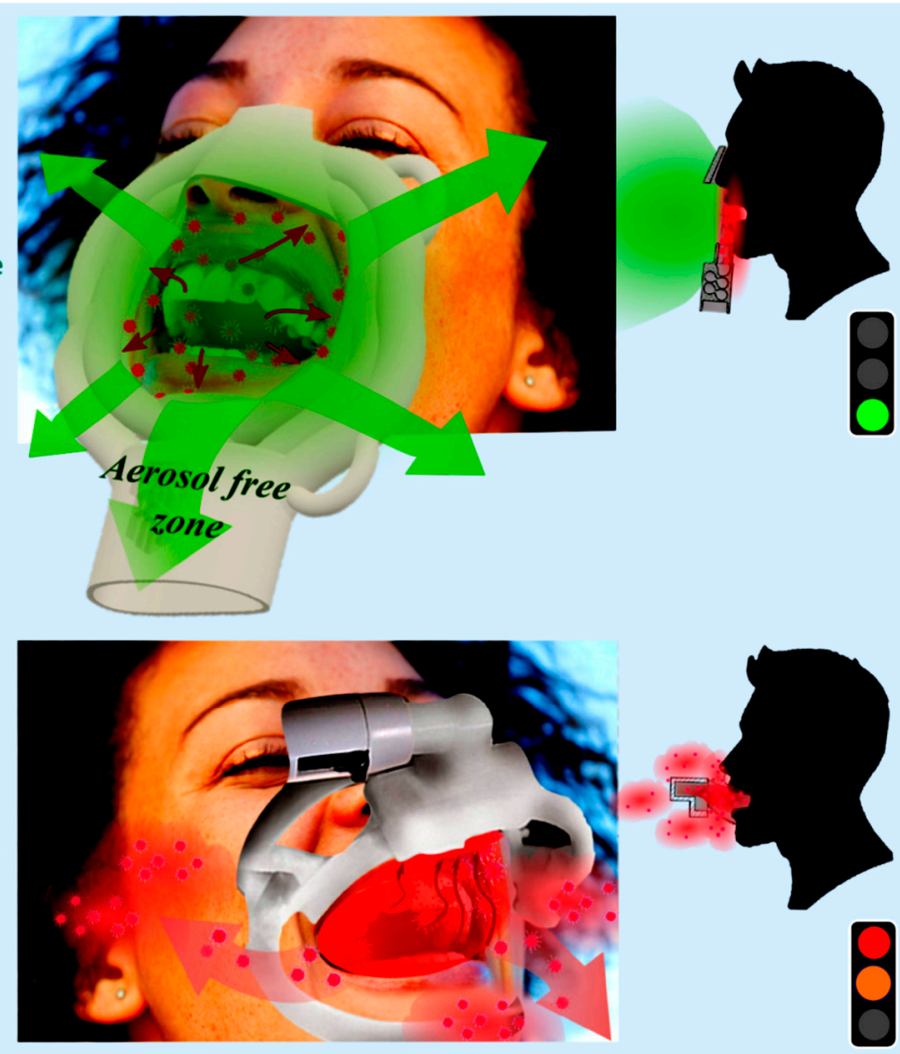

Figure 12. Comparison of the effectiveness of SARS-CoV-2 virus capture by a proprietary face cap and a solution available on the Internet.

\section{Engineering Aspects of Digitized Design and Manufacturing of an Authors Device for Dental} Purposes that Protect the Doctor and Medical Staff against the SARS-CoV-2 Coronavirus

In accordance with the concept of "Dentistry 4.0" [7,8], in the design and optimization of the device structure, the results of own work and information obtained by means of intraoral scanning and Cone Beam Computed Tomography (CBCT), on which own work has been carried out for about 10 years, are used. CBCT images are taken on a Gendex GXDP-700 laser device, with the SmartLogic technology applied. These data are used to develop typical 3D models of the morphology, structure, and dimensions of human faces. This is the basis for the development of a design and dimensional series of face caps with the greatest possible adaptation to the anatomical features of patients. Thus, the number of solutions, due to the anatomical dimensions of the patients, is finite and divided into quartiles. Data in the form of a set of photos DCM (DICOM Digital Imaging and Communications in Medicine image shorter DCM) taken at a certain thickness, collected during the CBCT examination are converted into data, three-dimensional models using specialized Materialize Mimics software. Using additional modules, CAD (computer-aided design) operations related to the design of face caps based on image data are performed, as well as virtual optimization using the so-called virtual twin. This allows for the proper simulation of the anatomy of the face and classification into dimensional quartiles. The implementation of virtual models according to the described methodology enables the transfer of appropriate data in the form of a three-dimensional model in STL (stereolithography or Standard Tessellation Language) format to the appropriate CAD software, in which geometric features of individual types of face caps are designed. A digital model of the oral cavity with a generated aerosol is being developed with the possibility of simulating the performance of various medical procedures generating a different amount of aerosol, including scaling and sandblasting of the side teeth, front teeth at the top or bottom, conservative treatment of teeth in various locations in the oral cavity, performing surgical procedures, as well as ear, nose, and throat (ENT) examination, 
ENT procedures. The model includes models of various aerosol sources, including a dental turbine, a dental blower, a dental sandblaster, and devices. The model also enables the simulation of aerosol generation depending on the conditions necessary for the various configurations of the mouth-aerosol source, and the dimensional category of the face cap and different suction force. The developed models are the basis for the design of each element of the device settings and for determining the critical places of the entire system due to the adhesion of viruses and other microorganisms, and by successive iterations, it is possible to minimize their harmful significance. In addition, digitized engineering design includes material design and selection of appropriate materials in order to minimize the impact of critical points (e.g., pipeline kinks), designing zones throughout the suction line of the device, where it is necessary to make appropriate hydrophobic nanostructured layers $\mathrm{Al}_{2} \mathrm{O}_{3}$ and/or TiO 2 to prevent the adhesion of viruses and bacteria by the atomic layer deposition (ALD) method [21] and coatings with $\mathrm{ZnO}_{2} / \mathrm{ZnO}$ quantum dots with a diameter of approx. $3 \div 5 \mathrm{~nm}$, functionalized hydrocarbon chains, e.g., $\mathrm{C}_{10} \mathrm{H}_{22}$ dispersed in an acrylate carrier, and virtual verification of selected materials, applied by immersion.

The described manufacturing method was developed on the basis of computer-processed data obtained with the use of CAD technology and Computer-Aided Manufacturing (CAM) using the AM (additive manufacturing) technology. The use of machining in the Computerized Numerical Control (CNC) Robodril CNC milling center by Fanuc and the ladle polymerization techniques of photopolymers, especially the stereolithographic SLS method, were analyzed, as well as others, including cDLM (Continuous Digital Light Manufacturing), DPP (Daylight Polymer Printing), DLP (Digital Light Printing) generally referred to as DLP (Figure 13, Table 3).

The material consumption was analyzed by comparing the manufacturing of device elements by machining from polymer discs with a diameter of $98.2 \mathrm{~mm}$, because such holders are available in the machine tool and SLA manufacturing (Figure 13). It has been shown that the material savings ratio in the case of using additive methods is $1: 16 \div 20$.

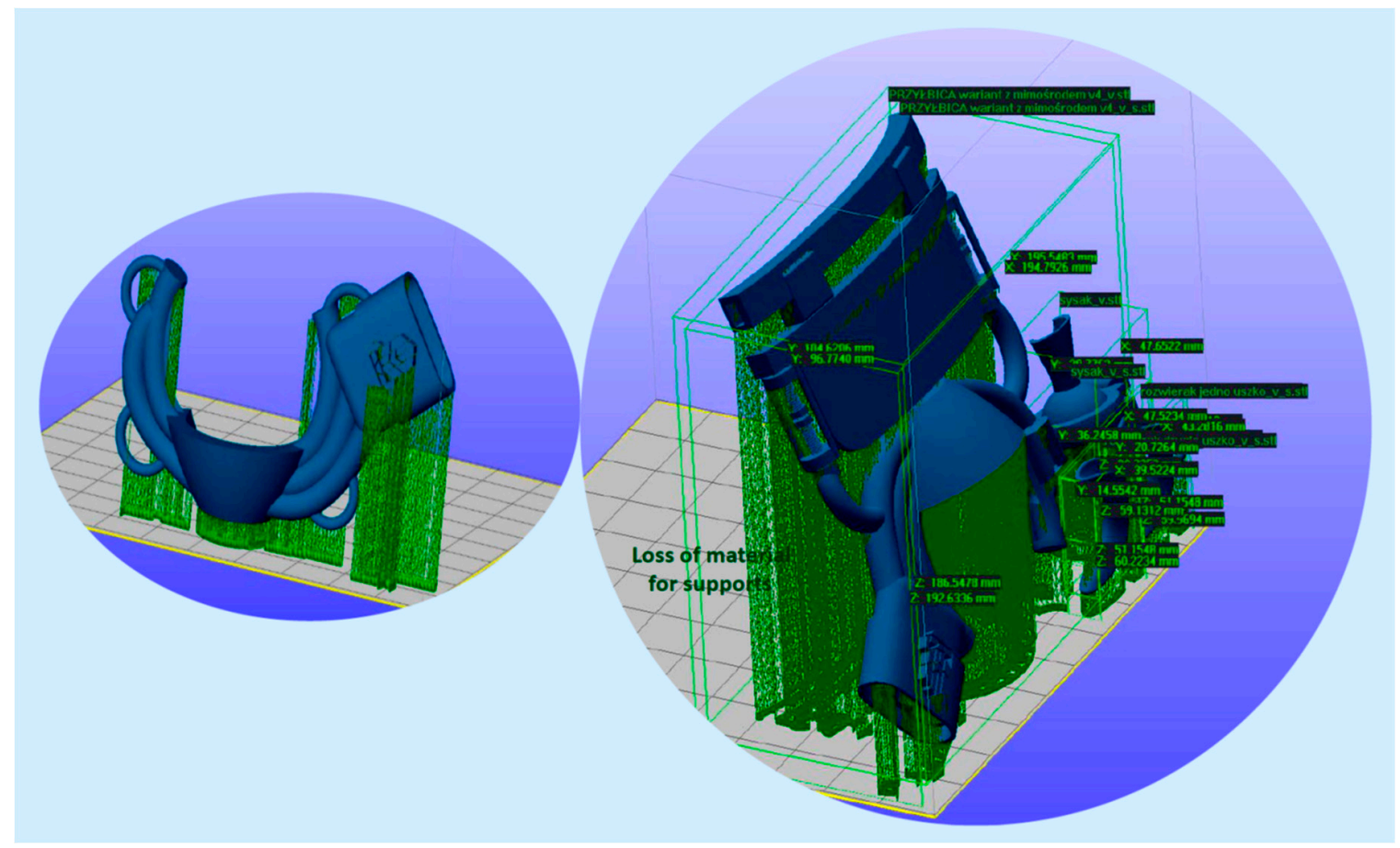

Figure 13. Diagram of the production of basic and advanced face caps using the stereolithography method.

Manufacturing with the additive method requires the creation of a virtual model showing the size, shape, and geometric features of individual elements in the STL format using appropriate CAD software, which is the basis for the implementation of a virtual technological model of these 
elements using the method of repeating base cells. The prepared model of all elements of the device is successively transferred to the CAM software, which is the basis for controlling the technological machine, where each element of the device is sequentially manufactured. Depending on the type of the element and the material used for this element, the SLA stereolithography method, and more preferably DLP, is used, since no manufacturing precision is required, and the production time can be significantly reduced by the DLP method. SLS (M) Selective Laser Sintering (Melting) or Electron Beam Melting (EBM) is used for a small number of metal components, and holes and threads are produced by machining in a CNC milling center when required CNC with the use of innovative additive technology aided by computer design of materials ADD-MAT [22]. After completion of the manufacturing stage, etching procedures are carried out, shaping the desired structure (texture) of the surface of the elements, and also applied surface treatment, e.g., by applying the ALD method, and in some places by immersion of coatings with quantum dots [21], followed by a sterilization procedure. The components of the device require sterilization prior to treatment and can be used repeatedly for various treatments, provided that each time is sterilized before the procedure.

Table 3. Analysis of the consumption of polymer/photopolymer materials in the case of the production of device elements by machining from polymer discs and the SLA method from light-cured polymers.

\begin{tabular}{|c|c|c|c|c|c|c|}
\hline Version & $\begin{array}{l}\text { Model Volume } \\
\qquad\left[\mathrm{cm}^{3}\right]\end{array}$ & $\begin{array}{c}\text { SLA } \\
\text { Approximate } \\
\text { Material Loss } \\
\text { (Supports) } \\
{\left[\mathrm{cm}^{3}\right]}\end{array}$ & $\begin{array}{c}\text { Number of } \\
\text { Discs Used for } \\
\text { Details } \\
\text { Manufacturing }\end{array}$ & $\begin{array}{c}\text { Volume of the } \\
\text { Working Space } \\
\text { of the Disc } \\
{\left[\mathrm{cm}^{3}\right]}\end{array}$ & $\begin{array}{c}\text { Total Volume } \\
\text { of Disks } \\
{\left[\mathrm{cm}^{3}\right]}\end{array}$ & $\begin{array}{c}\text { CNC } \\
\text { Approximate } \\
\text { Material Loss } \\
{\left[\mathrm{cm}^{3}\right]}\end{array}$ \\
\hline basic & 72.15 & 1.97 & 9 & \multirow{2}{*}{177.12} & 1594.04 & 1521.89 \\
\hline expanded & 150.35 & 48.4 & 19 & & 3365.2 & 3214.84 \\
\hline
\end{tabular}

\section{Recapitulation}

The world is in a very strange place. We could find a few songs that describe such a situation, although none of their authors imagined that they could correspond to such a global scale and such complex problems. One can mention the English version of Czesław Niemen's song "Strange Is This World" written in Polish in 1967 and in English in 1972. Suddenly, within a matter of days, normal development was interrupted in many areas and in 218 countries and territories. This applies to private matters of each of the 7,802,780,000 inhabitants of the Earth (this is exactly how many of us were on 5 August 2020, at 4:17 AM) [23], but also to entire societies and many areas of life: culture, education, science, economy, including industry ... A man should learn humility towards the majesty of Nature, even if his mistakes synergistically enhanced the highly negative effect.

Recapitulating activities identified by the subject of this paper and the thoughts contained in it can be presented on several points as follows:

I. In the case that is dear to the authors, i.e., dentistry and dental engineering, the principle of "stay at home" quickly turned into another "do nothing", because contacting the patient you can contract a deadly disease [24-28]. The Hippocratic Oath and ethics ...? [29]. We quickly developed the authors' SPEC strategy, which involves activity, not passive waiting, and hitting the heart of the problem to remove the cause that makes our life difficult. Of course, we know that the solution at the root of this problem is to invent the right vaccine. On 14 August 2020, the European Union concluded an agreement with AstraZeneca, cooperating with the University of Oxford, to purchase 300 million doses of the vaccine. The AstraZeneca vaccine is already in Phase II/III of large-scale clinical trials. Talks are also being held with other vaccine manufacturers, i.e., Sanofi-GSK, Johnson \& Johnson, CureVac, and Moderna [30]. U.S. government placed a similar agreement with Pfizer and Biontech and on 22 July 2020, and submitted an initial order of 100 million doses and can acquire up to 500 million additional doses [31]. But we still do not know when these vaccines will actually be delivered to recipients. We have to wait until this process ends positively. 
II. We want to help people by treating their sick teeth and removing the effects of these diseases, which can have a very complex impact on the health of many people. There is a high risk of complications, not only local but also systemic, resulting from pulp diseases [32]. Bacterial endocarditis, coronary artery disease, cerebral abscess, stroke, rheumatoid arthritis, osteoporosis, nephritis, pneumonia, and even preterm labor can be caused by an oral disease primary lesion [33-39]. In a favorable situation, caries and periodontal diseases may directly contribute to the patient's death.

III. It is obvious that the lack of teeth causes serious diseases [40-50]. It is possible to include chronic inflammatory changes gastric mucosa, upper gastrointestinal and pancreatic cancer, and an increased incidence of duodenal ulcers apart from aesthetic considerations. Tooth loss causes malocclusion, which affects the metabolism of the cerebrospinal fluid that nourishes the brain. The consequence may be headaches, migraines, pains in the cervical spine, and mood disorders, and also obstructive sleep apnea and neurocognitive dysfunction. Completely edentulous patients are more prone to electrocardiographic abnormalities, hypertension, heart failure, ischemic heart disease, stroke, aortic sclerosis, and coronary plaque formation. Toothlessness is a predictor of cardiovascular mortality. It may also cause rheumatoid arthritis, chronic kidney disease, non-insulin-dependent diabetes mellitus, and some cancers. A higher number of illnesses comorbid on the toothlessness are existing.

IV. The consequence of caries and periodontal diseases is the necessity to insert implants and prosthetic restorations, including bridges and crowns. It allows us to alleviate the effects of these diseases, and even effectively eliminate some of them. Improving the bite may have a positive effect on reducing the symptoms of multiple sclerosis. The restoring the dentition in the elderly has a positive effect on the hippocampus in the temporal lobe of the cerebral forebrain, responsible, among others, for spatial memory and for creating and recreating episodic memories. The systemic effect of masticatory disorder is an epidemiological risk factor for dementia. Toothlessness is often the direct cause of shortening human life. Chewing dysfunction causes morphological and functional changes in the hippocampus while chewing helps to maintain the proper functions of the hippocampus [51-57].

V. The coming of the SARS-CoV-2 virus blocked almost all dental treatment activities. Most dental procedures in almost the entire world have been abandoned for many months [18-22], although starting from June/July 2020 adequately, the initial restrictions have been slightly relaxed in various countries, but not entirely waived. The result is an obvious deterioration in dental welfare and an exacerbation of the negative effects of all untreated oral diseases and the systemic comorbidities and diseases that are caused thereby, as described above. This is the conflict that is signaled in the title of this paper. On the other hand, it was its occurrence that forced the authors to be active in this area. Most likely, had it not been for this, they would never have addressed the matter. That is why it was decided that, despite the fact that this conflict arose, it is non-antagonistic because it mobilized the authors to act positively. The sooner the reasons underlying the decision to treat only emergency cases in dentistry are resolved, the sooner proper dental care will be provided again. The authors are deeply convinced that the solution proposed in this paper serves this matter well.

VI. This paper presents a breakthrough authors solution, implemented by the active SPEC strategy, and aims to eliminate clinical aerosol at the source by negative pressure aspirating bioaerosol at the patient's mouth line. The comparative benchmarking analysis and its results show that only the proprietary solution with a set of devices eliminates the threat at the source, while the remaining known methods do not meet the expectations in this aspect. It was only possible to solve this problem thanks to progress in advanced digitized production. Please note that the essence of the problem concerns the correct selection of materials to be used in the manufacture of this device and materials processing technologies with the use of additive technologies and surface engineering. 
VII. So the question arises whether, when this virus disappears and its pandemic will finally end, will our solution still be needed. That's it. This pandemic has taught the people something, Nature has let the people know about its enormous power and helplessness of people, although they consider themselves the masters of the situation on Earth. As we can see, it is not so. Viruses live with us and next to us. Every now and then, some epidemic breaks out, i.e., Spanish flu, avian flu, swine flu, cholera, Ebola, SARS 1 and 2, and flu every year $[58,59]$. They are diseases that take thousands of lives. Each disease transmitted by airborne droplets requires protection, e.g., the way is presented in this paper. This has to be done routinely because we never know who is infected.

VIII. Despite the tragic events that inspired this action, the general conclusion is optimistic. The authors have found a solution to the problem that seriously threatens us.

Author Contributions: Conceptualization, Literature review, Presentation way-L.A.D. and L.B.D., Design, Resources, Data Curation, Software, Formal Analysis, Practical verification, Writing-Original Draft Preparation, Visualization-L.A.D., L.B.D., A.D.D.-D., J.D., K.R., A.A.-F., Writing-Review \& Editing, Supervision, Project Administration, Funding Acquisition-L.A.D. and L.B.D. All authors have read and agreed to the published version of the manuscript.

Funding: The paper is prepared due to the sending of the Project application no.: POIR.01.01.01-00-0637/20 cleanDENTworkspace- - medical aerosol absorption system generated during medical procedures in the patient's mouth during dental, ENT and general medical procedures in order to effectively protect personnel and patients against viruses (including SARS-CoV-2) and other microorganisms, 04.06.2020 and actually implemented Project POIR.01.01-00-0485/16-00 on 'IMSKA-MAT Innovative dental and maxillofacial implants manufactured using the innovative additive technology supported by computer-aided materials design ADD-MAT 'realized by the Medical and Dental Engineering Center for Research, Design and Production ASKLEPIOS in Gliwice, Poland. The project is implemented in 2017-2021 and is co-financed by the Operational Program Intelligent Development of the European Union.

Conflicts of Interest: The authors declare no conflict of interest.

Intention: Authors Leszek A. Dobrzański, Lech B. Dobrzański, and Anna Dobrzańska-Danikiewicz dedicated their participation in the preparation of this work to the memory of the Beloved Mother and Grandmother of the late Krystyna Stefania Dobrzańska née Kuczyńska on the hundredth anniversary of her birth on 27 September 1920.

\section{References}

1. Kagermann, H.; Wahlster, W.; Helbig, J. Recommendations for Implementing the Strategic Initiative INDUSTRIE 4.0: Final Report of the Industrie 4.0 Working Group; Federal Ministry of Education and Research: Bonn, Germany, 2013.

2. Rüßmann, M.; Lorenz, M.; Gerbert, P.; Waldner, M.; Justus, J.; Engel, P.; Harnisch, M. Industry 4.0: The Future of Productivity and Growth in Manufacturing Industries; Boston Consulting Group: Boston, MA, USA, 2015.

3. European Commision. Commission Sets out Path to Digitise European Industry; European Commission: Brussels, Belgium, 2016; Available online: http://web.archive.org/web/20200403145542/https://ec.europa.eu/ commission/presscorner/detail/en/IP_16_1407 (accessed on 17 August 2020).

4. Dobrzański, L.A.; Dobrzańska-Danikiewicz, A.D. Why Are Carbon-Based Materials Important in Civilization Progress and Especially in the Industry 4.0 Stage of the Industrial Revolution. Mater. Perform. Charact. 2019, 8, 337-370. [CrossRef]

5. Dobrzański, L.A.; Dobrzańska-Danikiewicz, A.D. Applications of Laser Processing of Materials in Surface Engineering in the Industry 4.0 Stage of the Industrial Revolution. Mater. Perform. Charact. 2019, 8, 1091-1129. [CrossRef]

6. Dobrzański, L.A. Effect of Heat and Surface Treatment on the Structure and Properties of the Mg-Al-Zn-Mn Casting Alloys. In Magnesium and Its Alloys; CRC Press: Boca Raton, FL, USA, 2019; pp. 91-202.

7. Dobrzański, L.A.; Dobrzański, L.B. Approach to the Design and Manufacturing of Prosthetic Dental Restorations According to the Rules of Industry 4.0. Mater. Perform. Charact. 2020, 9, 394-476. [CrossRef]

8. Dobrzański, L.A.; Dobrzański, L.B. Dentistry 4.0 Concept in the Design and Manufacturing of Prosthetic Dental Restorations. Processes 2020, 8, 525. [CrossRef] 
9. United Nations Industrial Development Organization. Industrial Development Report 2020. Industrializing in the Digital Age. 2019. Available online: https:/www.unido.org/sites/default/files/files/2019-11/UNIDO_ IDR2020-MainReport_overview.pdf (accessed on 17 August 2020).

10. CDC; Eckert, A.; Higgins, D. Available online: https://phil.cdc.gov/Details.aspx?pid=23312 (accessed on 17 August 2020).

11. WHO. Coronavirus Disease (COVID-19) Dashboard Data. Available online: https://covid19.who.int/ (accessed on 17 August 2020).

12. May, B. Research Briefing/Global Coronavirus Watch: Cautious pessimism warranted (Oxford Economic, 20 July 2020). Available online: http://blog.oxfordeconomics.com/coronavirus/cautious-pessimismwarranted (accessed on 17 August 2020).

13. Meng, L.; Hua, F.; Bian, Z. Coronavirus Disease 2019 (COVID-19): Emerging and Future Challenges for Dental and Oral Medicine. J. Dent. Res. 2020, 99, 481-487. [CrossRef]

14. Raport Amnesty International MJM, Pracownicy Medyczni na Całym Świecie są Uciszani, Narażani i Atakowani. Available online: https://amnesty.org.pl/pracownicy-medyczni-na-calym-swiecie-sa-uciszaninarazani-i-atakowani/ (accessed on 17 August 2020).

15. Van Doremalen, N.; Bushmaker, T.; Morris, D.H.; Holbrook, M.G.; Gamble, A.; Williamson, B.N.; Tamin, A.; Harcourt, J.L.; Thornburg, N.J.; Gerber, S.I.; et al. Aerosol and Surface Stability of SARS-CoV-2 as Compared with SARS-CoV-1. N. Engl. J. Med. 2020, 382. [CrossRef] [PubMed]

16. Fallahi, H.R.; Keyhan, S.O.; Zandian, D.; Kim, S.-G.; Cheshmi, B. Being a front-line dentist during the Covid-19 pandemic: a literature review. Maxillofac. Plast. Reconstr. Surg. 2020, 42, 1-9. [CrossRef] [PubMed]

17. Yonis, O.B.; Alyahya, M.; Khader, Y.S.; Al Nsour, M.; Al-Batayneh, O.B.; Saadeh, R.; Bashier, H.; Alfaqih, M.; Al-Azzam, S.; Alshurman, B.A. Dentists' Awareness, Perception, and Attitude Regarding COVID-19 and Infection Control: Cross-Sectional Study Among Jordanian Dentists. JMIR Public Health Surveill. 2020, 6, e18798. [CrossRef]

18. Dobrzański, L.B.; Dobrzański, L.A.; Dobrzańska, J.; Rudziarczyk, K.; Achtelik-Franczak, A. Akcesorium do ochrony osobistej personelu dentystycznego przed koronawirusem SARS-CoV-2 i innymi drobnoustrojami chorobotwórczymi. Zgłoszenie patentowe P.434391, Poland, data zgłoszenia: 19.06.2020 r.

19. Dobrzański, L.B.; Dobrzański, L.A.; Dobrzańska, J. CleanDENTworkspace-A medical aerosol absorption system generated during medical procedures in the patient's mouth during dental, ENT and general medical procedures in order to effectively protect personnel and patients against viruses (including SARS-cov-2) and other microorganisms (wniosek o dofinansowanie Projektu nr: POIR.01.01.01-00-0637/20, 04.06.2020 złożony do NCBiR, Warsaw, Poland).

20. Dobrzańska-Danikiewicz, A.D. Księga Technologii Krytycznych Kształtowania Struktury i Własności Powierzchni Materiałów Inżynierskich; International OCSCO World Press: Gliwice, Poland, 2013; pp. 1-823.

21. Dobrzański, L.A.; Dobrzańska-Danikiewicz, A.D. Inżynieria Powierzchni Materiałów: Kompendium Wiedzy $i$ Podręcznik Akademicki; International OCSCO World Press: Gliwice, Poland, 2018; pp. 1-1138.

22. Dobrzański, L.A.; Dobrzański, L.B. Innovative Dental and Maxillo-Facial Implant-Scaffold Manufactured Using the Innovative Technology and Additive Computer-Aided Materials Design. Medical and Dental Engineering Centre for Research; Design, and Production: Gliwice, Poland, 2017-2021.

23. Available online: https://www.worldometers.info/watch/world-population/ (accessed on 5 August 2020).

24. Guidance for Dental Settings, Interim Infection Prevention and Control Guidance for Dental Settings during the Coronavirus Disease 2019 (COVID-19) Pandemic. Available online: https://www.cdc.gov/coronavirus/ 2019-ncov/hcp/dental-settings.html (accessed on 28 August 2020).

25. Management of Acute Dental Problems during COVID-19 Pandemic. Available online: https://www.sdcep. org.uk/published-guidance/acute-dental-problems-covid-19/ (accessed on 28 August 2020).

26. Dental Care and Coronavirus (COVID-19). Available online: https://www.dentalhealth.org/Pages/FAQs/ Category/coronavirus (accessed on 28 August 2020).

27. Guidance on COVID-19, Guidance on Managing Infection Related Risks in Dental Services. Available online: https://www.fdiworlddental.org/sites/default/files/media/documents/guidance_on_ managing_infection_related_risks_in_dental_services_0.pdf (accessed on 28 August 2020).

28. COVID-19 and Dental Practice; What Has Been Done in China? Available online: https: //www.fdiworlddental.org/sites/default/files/media/documents/covid-19_and_dental_practice_what_has_ been_done_in_china.pdf (accessed on 28 August 2020). 
29. WMA Declaration of Geneva (adopted by the 2nd General Assembly of the World Medical Association, Geneva, Switzerland, September 1948 and amended by the 22nd World Medical Assembly, Sydney, Australia, August 1968 and the 35th World Medical Assembly, Venice, Italy, October 1983 and the 46th WMA General Assembly, Stockholm, Sweden, September 1994 and editorially revised by the 170th WMA Council Session, Divonne-les-Bains, France, May 2005 and the 173rd WMA Council Session, Divonne-les-Bains, France, May 2006 and amended by the 68th WMA General Assembly, Chicago, United States, October 2017). Available online: https://www.wma.net/policies-post/wma-declarationof-geneva/ (accessed on 28 August 2020).

30. Convention for the Protection of Human Rights and Fundamental Freedoms, Rome. Refug. Surv. Q. 2005, 24, 147-148. [CrossRef]

31. Coronavirus: Commission Reaches First Agreement on a Potential Vaccine. Available online: https: //ec.europa.eu/commission/presscorner/detail/en/ip_20_1438 (accessed on 28 August 2020).

32. Pfizer and Biontech Announce an Agreement with U.S. Government for up to 600 Million Doses of Mrna-Based Vaccine Candidate against sars-cov-2. Available online: https://www.pfizer.com/news/press-release/pressrelease-detail/pfizer-and-biontech-announce-agreement-us-government-600 (accessed on 28 August 2020).

33. Al-Nawas, B.; Maeurer, M. Severe versus Local Odontogenic Bacterial Infections: Comparison of Microbial Isolates. Eur. Surg. Res. 2007, 40, 220-224. [CrossRef]

34. Mueller, A.; Saldamli, B.; Stübinger, S.; Walter, C.; Flückiger, U.; Merlo, A.; Schwenzer-Zimmerer, K.; Zeilhofer, H.-F.; Zimmerer, S. Oral bacterial cultures in nontraumatic brain abscesses: Results of a first-line study. Oral Surg. Oral Med. Oral Pathol. Oral Radiol. Endodontol. 2009, 107, 469-476. [CrossRef] [PubMed]

35. Li, X.; Tronstad, L.; Olsen, I. Brain abscesses caused by oral infection. Dent. Traumatol. 1999, $15,95-101$. [CrossRef] [PubMed]

36. Scannapieco, F.A. Role of Oral Bacteria in Respiratory Infection. J. Periodontol. 1999, 70, 793-802. [CrossRef]

37. Scannapieco, F.A.; Bush, R.B.; Paju, S. Associations between Periodontal Disease and Risk for Nosocomial Bacterial Pneumonia and Chronic Obstructive Pulmonary Disease. A Systematic Review. Ann. Periodontol. 2003, 8, 54-69. [CrossRef]

38. Alexander, M.; Krishnan, B.; Shenoy, N. Diabetes mellitus and odontogenic infections—an exaggerated risk? Oral Maxillofac. Surg. 2008, 12, 129-130. [CrossRef] [PubMed]

39. López, N.J.; Smith, P.C.; Gutiérrez, J. Periodontal Therapy May Reduce the Risk of Preterm Low Birth Weight in Women with Peridotal Disease: A randomized Controlled Trial. J. Periodontol. 2002, 73, 911-924. [CrossRef] [PubMed]

40. Pallasch, T.J.; Wahl, M.J. Focal infection: New age or ancient history? Endod. Top. 2003, 4, 32-45. [CrossRef]

41. Burzyńska, B.; Mierzwińska-Nastalska, E. Rehabilitacja protetyczna pacjentów bezzębnych. Nowa Stomatol. 2011, 4, 167-169.

42. Felton, D.A. Edentulism and Comorbid Factors. J. Prosthodont. 2009, 18, 88-96. [CrossRef]

43. Felton, D.A. Complete Edentulism and Comorbid Diseases: An Update. J. Prosthodont. 2015, 25, 5-20. [CrossRef]

44. Abnet, C.C.; Qiao, Y.-L.; Dawsey, S.M.; Dong, Z.-W.; Taylor, P.R.; Mark, S.D. Tooth loss is associated with increased risk of total death and death from upper gastrointestinal cancer, heart disease, and stroke in a Chinese population-based cohort. Int. J. Epidemiol. 2005, 34, 467-474. [CrossRef] [PubMed]

45. Sierpinska, T.; Golebiewska, M.; Dlugosz, J.; Kemona, A.; Laszewicz, W. Connection between masticatory efficiency and pathomorphologic changes in gastric mucosa. Quintessence Int. 2007, 38, 31-37. [PubMed]

46. Bagchi, S.; Tripathi, A.; Tripathi, S.; Kar, S.; Tiwari, S.C.; Singh, J. Obstructive Sleep Apnea and Neurocognitive Dysfunction in Edentulous Patients. J. Prosthodont. 2018, 28, e837-e842. [CrossRef] [PubMed]

47. Völzke, H.; Schwahn, C.; Hummel, A.; Wolff, B.; Kleine, V.; Robinson, D.M.; Dahm, J.B.; Felix, S.B.; John, U.; Kocher, T. Tooth loss is independently associated with the risk of acquired aortic valve sclerosis. Am. Hear. J. 2005, 150, 1198-1203. [CrossRef]

48. Takata, Y.; Ansai, T.; Matsumura, K.; Awano, S.; Hamasaki, T.; Sonoki, K.; Kusaba, A.; Akifusa, S.; Takehara, T. Relationship between tooth loss and electrocardiographic abnormalities in octogenarians. J. Dent. Res. 2001, 80, 1648-1652. [CrossRef]

49. Holmlund, A.; Holm, G.; Lind, L. Number of Teeth as a Predictor of Cardiovascular Mortality in a Cohort of 7674 Subjects Followed for 12 Years. J. Periodontol. 2010, 81, 870-876. [CrossRef] 
50. De Pablo, P.; Dietrich, T.; McAlindon, T.E. Association of periodontal disease and tooth loss with rheumatoid arthritis in the US population. J. Rheumatol. 2007, 35, 70-76.

51. Chen, H.; Iinuma, M.; Onozuka, M.; Kubo, K.-Y. Chewing Maintains Hippocampus-Dependent Cognitive Function. Int. J. Med Sci. 2015, 12, 502-509. [CrossRef]

52. Lexomboon, D.; Trulsson, M.; Wårdh, I.; Parker, M.G. Chewing Ability and Tooth Loss: Association with Cognitive Impairment in an Elderly Population Study. J. Am. Geriatr. Soc. 2012, 60, 1951-1956. [CrossRef]

53. Stein, P.S.; Desrosiers, M.; Donegan, S.J.; Yepes, J.F.; Kryscio, R.J. Tooth loss, dementia and neuropathology in the Nun Study. J. Am. Dent. Assoc. 2007, 138, 1314-1322. [CrossRef]

54. Henke, K. A model for memory systems based on processing modes rather than consciousness. Nat. Rev. Neurosci. 2010, 11, 523-532. [CrossRef] [PubMed]

55. Kawahata, M.; Ono, Y.; Ohno, A.; Kawamoto, S.; Kimoto, K.; Onozuka, M. Loss of molars early in life develops behavioral lateralization and impairs hippocampus-dependent recognition memory. BMC Neurosci. 2014, 15, 4. [CrossRef] [PubMed]

56. Onishi, M.; Iinuma, M.; Tamura, Y.; Kubo, K.-Y. Learning deficits and suppression of the cell proliferation in the hippocampal dentate gyrus of offspring are attenuated by maternal chewing during prenatal stress. Neurosci. Lett. 2014, 560, 77-80. [CrossRef] [PubMed]

57. Hirano, Y.; Obata, T.; Takahashi, H.; Tachibana, A.; Kuroiwa, D.; Takahahi, T.; Ikehira, H.; Onozuka, M. Effects of chewing on cognitive processing speed. Brain Cogn. 2013, 81, 376-381. [CrossRef] [PubMed]

58. Procyk-Lewandowska, I. Historia Pandemii na Świecie-Koronawirus SARS-CoV-2 na tle Innych Pandemii. Available online: https://www.medicover.pl/o-zdrowiu/historia-pandemii-na-swiecie-koronawirus-sarscov-2-na-tle-innych-pandemii,6788,n,168 (accessed on 28 August 2020).

59. Hays, J.N. Epidemics and Pandemics: Their Impacts on Human History; ABC-CLIO: Santa Barbara, CA, USA; Denver, CO, USA; London, UK, 2005.

(C) 2020 by the authors. Licensee MDPI, Basel, Switzerland. This article is an open access article distributed under the terms and conditions of the Creative Commons Attribution (CC BY) license (http://creativecommons.org/licenses/by/4.0/). 